\title{
First known gigantic sea turtle from the Maastrichtian deposits in Egypt
}

Gebely Abdel-Maksoud Abu El-Kheir, Mohamed Korany Abdelgawad, and Walid Gamal Kassab Acta Palaeontologica Polonica 66 (2), 2021: 349-355 doi:https://doi.org/10.4202/app.00849.2020

The Maastrichtian deposits in Egypt and generally in Africa contain very few records of chelonioids. This scarcity hinders understanding the evolution and extinction of African chelonioids during this age. The Dakhla Basin in Egypt presents excellent Maastrichtian outcrops that consist of highly fossiliferous, calcareous siltstone and sandstone layers rich in ammonites, bivalves (Exogyra overwagi, Pycnodonta vesicularis, pectinids), gastropods, echinoids, corals, fossilized fruits of mangrove plants (Nypa) and vertebrate remains. The well-preserved humerus of giant turtle and other vertebrate remains have been discovered in the early late Maastrichtian Ammonite Hill Member of the Dakhla Formation in the Abu Minqar area, Southern Western Desert, Egypt. The Ammonite Hill Member was deposited in very shallow coastal, inner neritic to littoral environments. The well-preserved giant humerus represents the first record of gigantic Mesozoic chelonioids in Africa and the second record of chelonioids in the Maastrichtian deposits in Egypt. The present specimen contributes to fill the missing gaps in the history of Egyptian turtles from the Cretaceous through the Cenozoic.

Key words: Testudines, Panchelonioidea, Cheloniidae, humerus, Cretaceous, Maastrichtian, Dakhla, Abu Minqar, Egypt.

Gebely Abdel-Maksoud Abu El-Kheir [gebely2006@sci.nvu.edu.eg;

ORCID: https://orcid.org/0000-0001-5905-8790], Department of Geology, Faculty of Sciences, New Valley University, New Valley, Kharga, Egypt.

Mohamed Korany AbdelGawad [mkabdelgawad@gmail.com; mkabdelgawad@sci.cu.edu.eg

; ORCID: https://orcid. org/0000-0002-3229-3800] and Walid Gamal Kassab [wkassab@sci.cu.edu.eg,

ORCID: https://orcid.org/0000-0001- 9882-9607] (corresponding author), Department of Geology,

Faculty of Science, Cairo University, Giza, Egypt.

This is an open-access article distributed under the terms of the Creative Commons Attribution License (for details please see creativecommons.org), which permits unrestricted use, distribution, and reproduction in any medium, provided the original author and source are credited. 
FoF Full text (894.9 kB) 